\title{
Varied Presentation of Oral Verrucous Carcinoma in a Tertiary Hospital of Dhaka City
}

\author{
T MAMUN ${ }^{\mathrm{a}}$, T RAHMAN ${ }^{\mathrm{b}}$, IA HAIDER ${ }^{\mathrm{c}}$, MRK RIPON $^{\mathrm{d}}$.
}

\begin{abstract}
Introduction: Ackerman's tumor or Verrucous carcinoma is a distinguished clinic-pathological variant of squamous cell carcinoma, presenting with multiple clinical presentations. This study provides a contemporary survey of morphological presentation of oral verrucous carcinoma $(O V C)$ in the oral cavity with site of predilection and possible etiological factors.
\end{abstract}

Method: An observational studywas conducted from January 2014 to June 2016.A suspected patient diagnosed clinically and histologically as OVC at the Dhaka Dental College Hospital (DDCH) was enrolled in this study.

Results: In this study total 15 number of patients male were $53.3 \%$ and female were $47 \%$.

\section{Introduction:}

Head and neck malignant carcinoma is the world's fifth most common cancer with incidence exceeding half a million annually. ${ }^{1,2}$ Oral squamous cell carcinoma (OSCC) represents $95 \%$ of head and neck malignant carcinoma. ${ }^{3}$ Oral verrucous carcinoma (OVC) accounts for $2-12 \%$ of all oral carcinomas. ${ }^{4}$ Verrucous carcinoma is a distinct clinico-pathological entity of oral squamous cell carcinoma.

Dr. Md, Talal Mamun BDS, FCPS (OMS), Consultant, Department of Oral and Maxillofacial Surgery, Al Haramain Hospital Pvt. Ltd, Sylhet, Bangladesh.

b. Dr. Tarin Rahman, BDS, MS(OMS), Associate Professor, Department of Oral and Maxillofacial Surgery, Dhaka Dental College and Hospital, Mirpur-14, Dhaka, Bangladesh.

c. Dr. Ismat Ara Haider, BDS, MS (OMS), Professor and Head, Department of Oral and Maxillofacial Surgery, Dhaka Dental College and Hospital, Mirpur-14, Dhaka, Bangladesh.

d. Dr. (Lt Col) Mohammad Rezaul Karim Ripon. BDS, MCPS, FCPS (OMS). Military Dental Center, Savar, Savar Cant.

Address of Correspondence: Dr. Md. Talal Mamun BDS, FCPS(OMS), Consultant, Department of Oral and Maxillofacial Surgery, Al Haramain Hospital Pvt. Ltd, Sylhet, Bangladesh.Mob- 01914901801. E-mail: talalmamun1984@gmail.com.
The morphological presentation of the study was proliferative and verrucous, each of which comprises $40.0 \%$ of cases. The tumor's primary site was the buccal mucosa $46.67 \%$ and history ofbetel quid chewing was $46.9 \%$.

Conclusion: The study concluded that it is very difficult to distinguishing clinically between verrucous carcinoma and other exophytic lesions of the oral cavity. OVC presents with different morphological presentation such as proliferative and verrucous types. Buccal mucosa is the site of predilection.

Keywords: Oral verrucous hyperplasia, Proliferative verrucous leukoplakia, Verrucous carcinoma.

(J Bangladesh Coll Phys Surg 2021; 39: 80-86)

DOI: https://doi.org/10.3329/jbcps.v39i2.52387

In 1948 Lauren V Ackerman was first described, which is also known as Ackerman's tumor. ${ }^{5}$

Various synonyms used to describe this tumor, such as Loewenstein tumor, florid oral papillomatosis, epitheliomacuniculatum and carcinoma cuniculatum. ${ }^{6}$ The mucous membrane of the head and neck are sites of predilection, with the oral cavity and larynx is the most common site of presentation. It also occurs in esophagus, para nasal sinus, nasal cavity, genitalia, skin \& sole of foot. This lesion appears as pain less, white warty, ulcerated or proliferative, soft fungating with mamillated surface and attached by a broad base resembling a cauliflower.

The tumor is predominantly common in male over the fifth to sixth decade. The clinical behavior of lesion is very destructive; it may grow very large in size and can also extensively infiltrate to destroy the adjacent tissues, including bones and cartilage. The etiopathology of the OVC is unknown, but strongly related with betel quid, tobacco use, also associated 
with oral precancerous lesion, alcohol \& human papilloma virus. The histological appearance of OVC is a well differentiated hyperplastic epithelial lesion. With heaving a densely keratinized surface and sharply defined deep margin. Aim of the study was to identify the OVC present with different morphological presentation and also different from other similar warty and exophytic oral lesion.

\section{Methods:}

Anobservational study was conducted atthe tertiary label oral and maxillofacial surgery departmentof Dhaka Dental College and Hospital (DDCH) between Jan 2014 to Jun 2016. It waspurposive sampling method study. Total fifteen patients enrolled who were clinically and pathologically proven OVC and fulfilled inclusion criteria. All patients was treated primarily by surgery and followed-up to two years. Ethical clearance was taken from the ethical committee DDCH prior to the study. Written consent was taken from all participating patients and kept their name and other information confidential throughout the study.

\section{Results:}

This study was carried out among 15 patients who are clinically and histopathologically diagnosed oral verrucous carcinoma in different sites of oral cavity. There were male 8 (53\%) and 7 (47\%) were female patient (ratio of M: F, 1.2:1). (Figure-1)

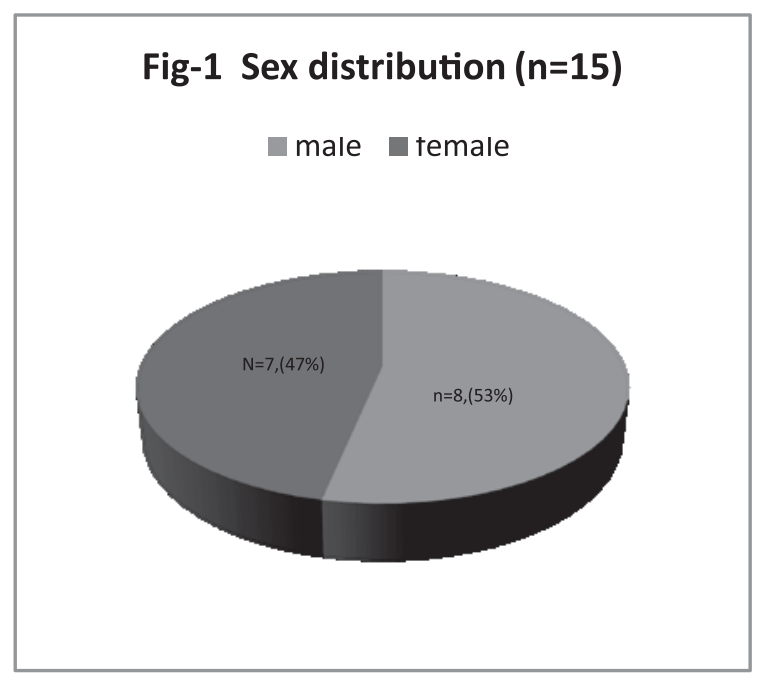

The age group (60-69) years was mostly affected (46.7\%) followed by age group (50-59) years was at $(40.0 \%)$ in the study population. (Table-I)

\begin{tabular}{|lcccc|}
\hline \multicolumn{5}{|c|}{ Table-I Age distribution (n-15) } \\
\hline $\begin{array}{l}\text { Age } \\
\text { range }\end{array}$ & Frequency & $\begin{array}{l}\text { Percent } \\
(\%)\end{array}$ & Mean & \\
\hline$<50$ & 2 & SD & \\
$50-$ & 6 & 13.3 & & \\
59 & & 40.0 & 2.333 & .72375 \\
$60-$ & 7 & & & \\
69 & & 46.7 & & \\
Total & 15 & & \\
SD- Std Deviation & & \\
\hline
\end{tabular}

The incidence of betel quid chewing, smoking, and both intake was 7 (46.9\%), 3 (20.0\%), and 2 (13.3\%), respectively. Leukoplakia, Sub Mucous Fibrosis and Verrucous hyperplasia each is also represent 1 (6.7\%) respectively. (Figure-2)

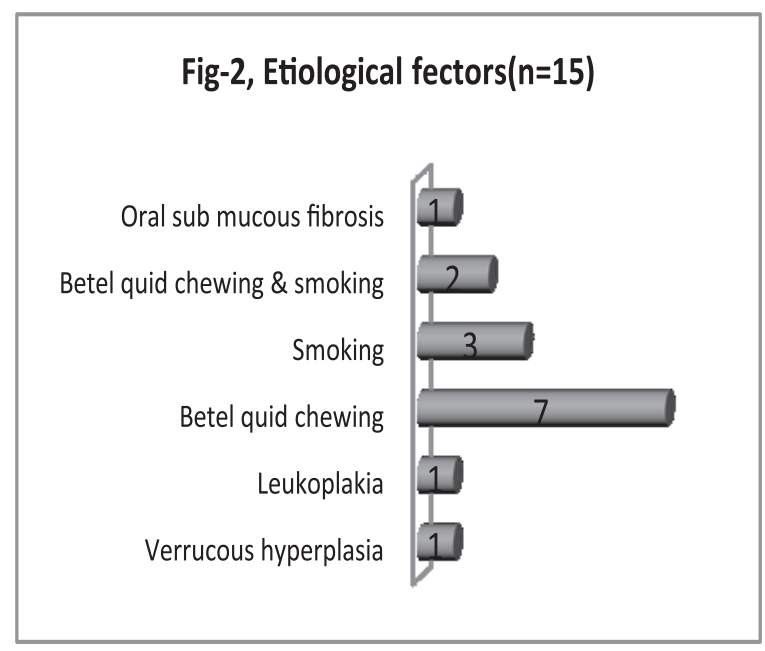

In study population most of the lesion involved in buccal mucosa 7 (46.67\%), multiple site (lower alveolus, floor of the mouth, buccal sulcus \&buccal mucosa) involved in $3(20 \%)$ cases and palatal mucosa involved in 2 (13.30\%) cases..(Figure-3) 


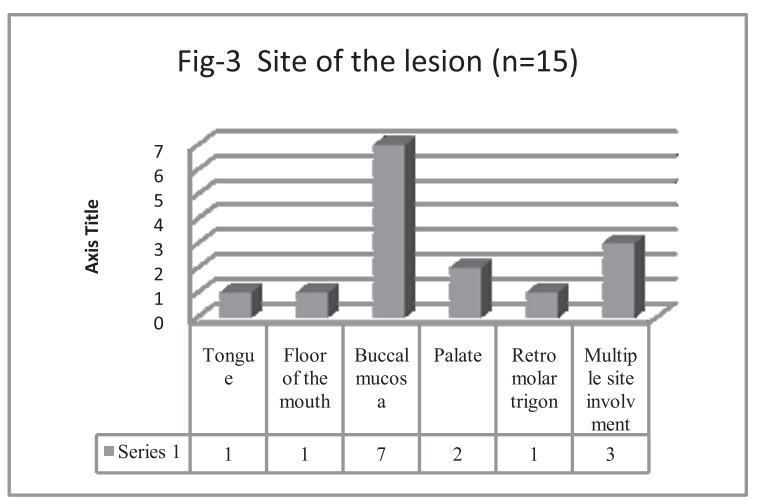

The most common morphological presentation of lesion was both 'proliferative' and 'verrucous' each of which comprising $6(40.0 \%)$ of the sample. followed by an ulcerative $2(13.3 \%)$ and ulcer proliferative growth $6.7 \%$. .(Table-II)

\begin{tabular}{|lccc|}
\hline \multicolumn{4}{|c|}{ Table-II: Morphological presentation $(\mathbf{n = 1 5})$} \\
\hline $\begin{array}{c}\text { Type of } \\
\text { presentation }\end{array}$ & Frequency & $\begin{array}{c}\text { Percent } \\
(\%)\end{array}$ & $\mathbf{\pm S D}$ \\
\hline Proliferative & 6 & 40.0 & \\
Verrucous & 6 & 40.0 & \\
Ulcerative & 2 & 13.3 & \\
& 1 & 06.7 & \\
$\begin{array}{l}\text { Ulcer } \\
\text { proliferative }\end{array}$ & 15 & 100 & \\
$\begin{array}{l}\text { Total= } \\
\text { SD- Std Deviation }\end{array}$ & & & \\
\hline
\end{tabular}

\section{Discussion:}

Verrucous carcinoma is a variant of oral squamous cell carcinoma characterized by a predominantly exophytic overgrowth of well-differentiated keratinizing epithelium having minimal atypia and with locally destructive pushing margins at its interface with underlying connective tissue. OVC present with a specific clinical and histological presentation, this distinguishable feature from squamous cell carcinoma (SSC) makes OVC pathology of interest in the field of research. As far known there are no relevant studies in our country (Bangladesh), which have evaluate the clinical presentation of OVC. An observational study was done with 15 patients, where male patients were 8 $(53 \%) \&$ female patient was $7(47 \%)$. The male female ratio was $1.2: 1$ mean age was 58.3 years. The common affected group was 60-69(46.7\%) years. The second most affected group 50-59 years was $40.0 \%$ and lowest group was below 50 years. Ray et al.seen most common in over sixth decade males. ${ }^{7} \mathrm{OVC}$ traditionally occurs more commonly in older males, above the sixth decade. ${ }^{8}$ In Brenton et al. review sixty percent of the patients were male and the median age was 67 years at diagnosis. ${ }^{9}$ Fonts et al. showed as equal sex distribution in their studies. ${ }^{10}$ Tadashi found female predominance (F-6 \& M-4) in his histological study of OVC in 10 Japanese patients. ${ }^{11}$ Hansenshows in his long term study over the thirty patients of OVC found (M: F is $1: 4) .{ }^{12}$ This dissimilarity may be due to their different habit, culture \& exposure of carcinogen.

The aetiology of OVC is not well known ${ }^{7}$ and the incidence of betel quid chewer was $46.9 \%$, smoker $20.0 \%$ and both user were $13.3 \%$ in our observation. Chung et al reported that $55.6 \%$ (five out of 9 patients) of the patients with verrucous lesions were areca quid chewers, and they suggested that areca quid chewing could be a major causative factor for these lesions in Taiwan. ${ }^{13} 50 \%$ of the patients smoked tobacco (six out of 12 patients), and they also suggested that cigarette smoking is the major risk factor for their OVC patients. ${ }^{14,15,16}$ Brenton et al. described the sources of the carcinogens include tobacco, alcohol, marijuana or cigarette smoking, and betel nut act as a predisposing factors. ${ }^{9}$ Spiro proposed tobacco \& betel quid chewing is a significant etiologic factor for the development of OVC. ${ }^{17}$ Jacobson and Shear surveyed 198 cases of OVC and described 15 personally-observed cases, where incidence of smoking was found to be $77 \%$ (7 out of 9 patients). ${ }^{18}$

Sundstrom et al \& Oliveira et al., also found the strong association of OVC with smoking, alcohol, and HPV infections. ${ }^{19,8}$ Verrucous carcinoma is suggestive association between $\mathrm{HPV}^{20} \mathrm{HPV}$ subtypes 6 and 11 were the most predominant identified HPV infections. ${ }^{21}$

Coexisting lesion leukoplakia was $6.7 \%$, oral SMF $6.7 \%$ and verrucous hyperplasia was $6.7 \%$ present in ourstudy population. Rajendran et al., recorded leukoplakia in association with OVC in $48 \%$ cases of their 426 patient observations. ${ }^{22}$ Brenton et al., suggested VC exists within the histological continuum ranging from benign squamous hyper plastic lesions to invasive squamous cell carcinoma. ${ }^{9} \mathrm{OVC}$ develop from premalignant lesion. $^{23,24}$ 


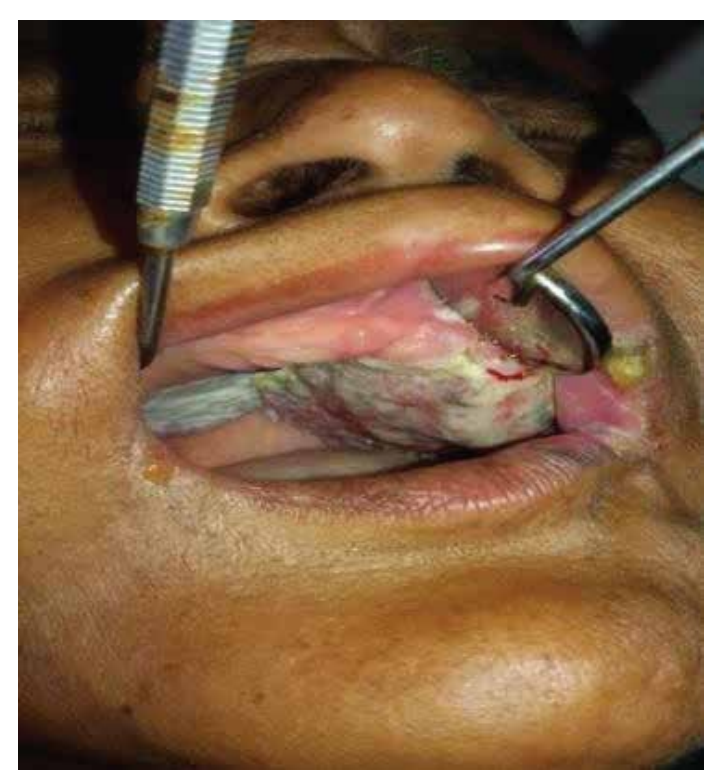

Figure 1: Proliferative type

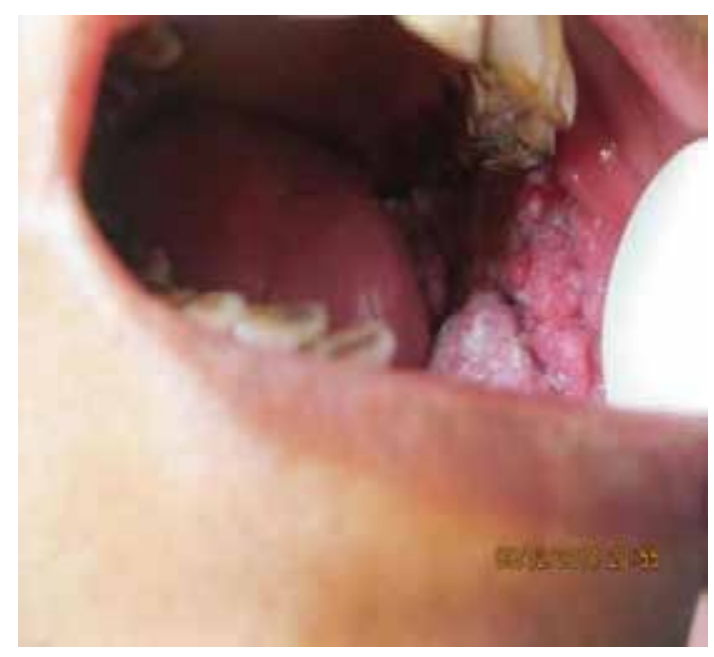

Figure 3: Ulcerative type

The presence of leukoplakic lesions and poor oral hygiene may also act as predisposing factors. ${ }^{14}$ Rohan et al., recorded in their 101 cases, $33.7 \%$ present leukoplakiaact as a predisposing factor. ${ }^{25}$ Demian et al., also recorded the clinical association with leukoplakia and OVC is significant since untreated

longstanding leukoplakia could progress to a verrucous cancer in time. ${ }^{26} 56.2 \%$ of PVL lesions can transform to squamous cell carcinoma orverrucouscarcinoma. ${ }^{27}$ Oral verrucous hyperplasia $(\mathrm{OVH})$ is a histological entity and precursor of oral verrucous carcinoma (OVC)that was first described

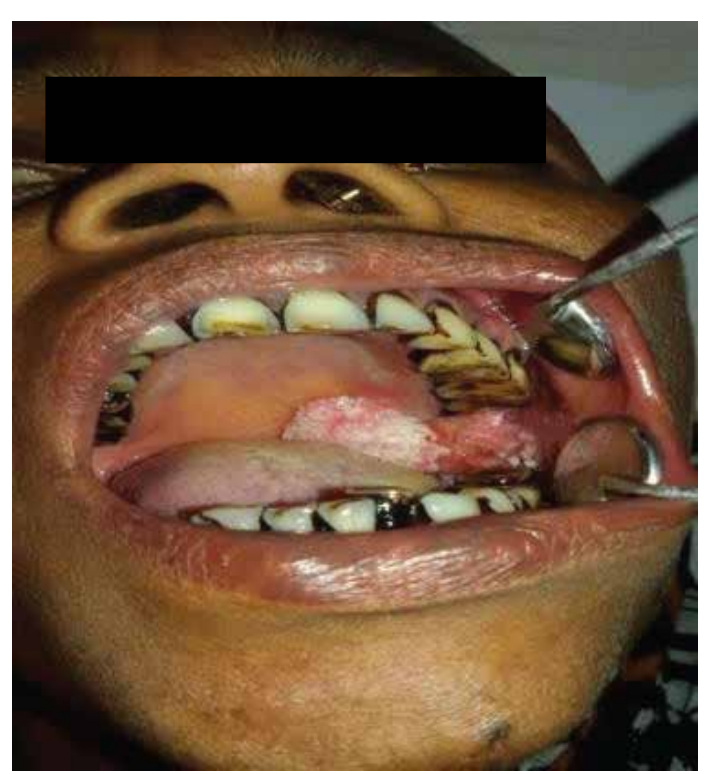

Figure 2: Verrucous type

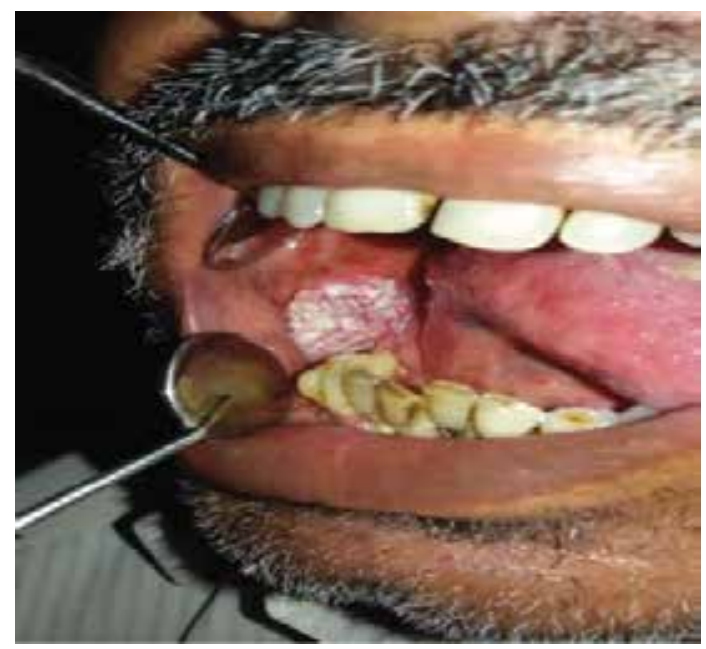

Figure 4: Ulcero-proliferative type

by Shear and Pindborg. ${ }^{23}$

Verrucous' terminology is applied for lesions that show exophytic, keratotic surfaces, made of blunt or sharp epithelial projections, filled with keratin invaginations, but without clear fibro vascular cores. ${ }^{7}$ The verrucous surface is the most characteristic feature of verrucous lesions $(\mathrm{OVH}$ and $\mathrm{OVC}$ lesions). Clinically, distinguishing $\mathrm{OVH}$ from OVC lesions is often difficult. ${ }^{28}$ There have been few clinicopathological studies in the literature on $\mathrm{OVH}$ and OVC, Wang et al., Rohanet al., RekhaAngadi and Zhu et al..$^{25,28,29,30}$ In generally, OVH is superficial 
lesion, adjacent to normal epithelium and does not extend into deeper tissues, whereas OVC spreads more deeply.$^{31}$

PVL presentation as cauliflower like and most common in buccal mucosa, palate, gingiva andtongue. ${ }^{32}$ Histologically, in early lesions of PVL present only hyperkeratosis, then over time they may progress to become verrucous and commonly show variable degrees of epithelial dysplasia and a sudden change from hyperparakeratosis to hyperorthokeratosis, associated withverruciform or ridged surfaces. ${ }^{33}$ But overall OVC has a better prognosis compared to other carcinomas. ${ }^{7}$

In this study the most common site of lesion wasbuccal mucosa $46.7 \%$, followed by multiple site (lower alveolus, buccal sulcus, and floor of the mouth) of oral cavity which is $20.0 \%$, palate $13.3 \%$, tongue $6.7 \%$, floor of the mouth $6.7 \%$ and retro molar trigon was $6.7 \%$. The most common site for OVC is the buccal mucosa. Yeh et al., Rohanet al., and Rekha and Angadi, also show similar presentation of their study.

However, the most affected areas in Alkanet al'sstudy were the mandibular area followed by buccalmucosa, ${ }^{14}$ and the predominant site of OVC lesions in Zhu etal'sstudy was lower lip. ${ }^{28}$ Jacobson et al., Regezi., Yoshimura., and Hashibe et al., suggest that verrucous carcinoma had predilection for the oral cavity; in particular the buccal mucosa and the lower alveolus. $^{23,28,36,37}$ Shear \&Pindborg., suggested OVC develop at the site where the betel quid \& tobacco was placed habitually. ${ }^{23}$ Fonts et al., Yeh C J. andAlperAlkan., found in their study that $41.6 \%$ cases OVC present in retro molar \& mandibular posterior alveolar crest area. ${ }^{10,14,34}$

In this study the most common morphological presentation of OVC was both proliferative and verrucous each of which comprising $6(40.0 \%)$ of the sample. Followed by ulcerative type which is $13.3 \%$ and ulcer proliferative type is $6.7 \%$. QianPeng et al., present his review article as the OVC are exophytc, cystoid and infiltrative types. ${ }^{38}$ Tang et al also divided OVC into three types: exogenic type, cystoid type, and infiltrative type. The exogenic type of OVC is characterized by exophytic growth, cauliflower-like warty lesion and slow tumor growth. However, the other two types of OVC grow rapidly, forming bean dreg-like white dry keratosis, accompanying poor prognosis compared to the exogenic type of OVC. ${ }^{39}$ Rohan et al., also recorded proliferative, verrucous, ulcerative, ulceroproiferrative \& infiltrative/sub mucous type of OVC in there study of 101 patient. ${ }^{25}$ Yoshimura \&Vivekanando et al., also recorded the similar presentation of OVC in their study. ${ }^{36,40}$ OVC present both benign and malignant processes, malignant ovc contain small foci of squamous cell carcinoma, which are known as a "hybrid" forms of verrucouscarcinoma. ${ }^{9}$

Generally speaking, the accurate histological classification of squamous mucosal lesions with an exophytic growth pattern is often difficult and requires experience. ${ }^{41}$ Hence, OVC clinico-histopathological diagnosis is usually exclusionary and extremely problematic. ${ }^{30}$

\section{Conclusion:}

Verrucous carcinoma present with different special morphological presentation with local invasiveness and non-metastasizing behavior. Most commonly seen with in buccal mucosa of oral cavity, and distinguishing of OVC from other exophytic lesions such as OVH, PVL is often difficult to clinicians, and also furthermore, distinguishing of different morphological presentation of OVC from classical (grade-I) OSCC is a common problem for pathologists due to poorly-defined diagnostic criteria. Thus both clinicians and pathologists must be careful about warty and exophytic lesions of oral cavity, and communicate with each other for better diagnosis.

\section{Reference :}

1. Jemal A, Bray F, Center MM, Ferlay J, Ward E and Forman D: Global cancer statistics. CA Cancer J Clin 2011; 61: 69-90. https://doi.org/10.3322/caac.20107 PMid:21296855

2. Fujii M. Multidisciplinary approach for the treatment of head and neck cancer.Int J ClinOncol2014; 19: 209-210. https://doi.org/10.1007/s10147-014-0670-x PMid:24519323

3. Rivera C, Venegas B. Histological and molecular aspects of oral squamous cell carcinoma (Review). OncolLett 2014; 8: 7-11. https://doi.org/10.3892/ ol.2014.2103, PMid:24959211 PMCid:PMC4063640 
4. Chaisuparat R, Limpiwatana S, Kongpanitkul S, Yodsanga Sand Jham BC: The Akt/mTOR pathway is activated in verrucous carcinoma of the oral cavity.J Oral Pathol Med: Jan 17; 2016. https://doi.org/10.1111/ jop.12422, PMid:26775690

5. Ackerman LV. Verrucous carcinoma of the oral cavity.Surgery, 1948; (23):670-8.

6. Schwartz RA. Verrucous carcinoma of the skin and mucosa.J Am AcadDermatol, 1995; 32:1-21. https://doi.org/10.1016/0190-9622(95)90177-9

7. Ray JG., Mukherjee S, Pattanayak MS,Chaudhuri K. Oral verrucous carcinoma-a misnomer? Immunohistochemistry based comparative study of two cases.BMJ case reports, 2011. https://doi.org/ $10.1136 /$ bcr. 11.2010 .3479$, PMid:22696703 PMCid:PMC3089934

8. Denise Tostes Oliveira, Renato Vieira de Moraes, Jorge Francisco FiamenguiFilho, Joao FantonNeto, Gilles Landman, LuizPaoulo Kowalski. Oral verrucous carcinoma: a retrospectivestudy in Sao Paulo Region, Brazil. Clin Oral Invest, 2006; 10(3):205-9. https://doi.org/10.1007/s00784-006-0050-7 PMid:16738900

9. Brenton B. Koch,Douglus K, Henry T, Lucy H, Robert A, Weining Zhen, et al. Cancer society. Atlanta, GA. National Survey of Head and Neck Verrucous Carcinoma.Ame Can Society 2001.

10. Fonts EA, Greenlaw RH, Rush BF, Rovin S.Verrucous squamous cell carcinoma of the oral cavity.Cancer,1969; 23(1):152-60. https://doi.org/ 10.1002/1097-0142(196901)23:1<152::AID-CNCR2 $820230120>3.0 . \mathrm{CO} ; 2-\mathrm{M}$

11. Tadashi Terada. Verrucous carcinoma of the oral cavity: A Histopathologic study of 10 Japanese cases. J Maxillofac oral surg, 2009; 10(2):148-151. https://doi.org/10.1007/s 12663-011-0197-x PMid:22654367 PMCid:PMC3177512

12. Hansen LS, Olson JA, Silverman S Jr. Proliferative verrucous leukoplakia: A long-term study of thirty patients. Oral Surg Oral Med Oral Pathol, 1985; 60:285. https://doi.org/10.1016/0030-4220(85)90313-5

13. Chung CH, Yang YH, Wang TY, Shieh TY, Warnakulasuriya S. Oral precancerous disorders associated with areca quid chewing, smoking \& alcohol drinking in southern Taiwan. J Oral Pathol Med, 2010; 34: 460-466. https://doi.org/10.1111/ j.1600-0714.2005.00332.x, PMid:16091112
14. Alper A,Emel B, Omer G. Oral Verrucous, A Study of 12 cases. Eur J Dent, 2010; 4:202-207. https://doi.org/10.1055/s-0039-1697831

15. Medina JE, Dichtel W, Luna MA. Verrucoussquamous carcinoma of the oral cavity: a clinicopathologic study of 104 cases. Arch Otolaryngol, 1984; 110:437-40. https://doi.org/ 10.1001 / archotol.1984.00800330019003, PMid:6732584

16. Saranath D, Chang SE, Deo MG. High frequency mutation in codons 12 and 61 of H-ras oncogene in chewing tobacco-related human oral carcinoma in India. Br L Cancer, 1991; 63:573-78. https://doi.org/ 10.1038/bjc.1991.133, PMid:2021541 PMCid:PMC1972357

17. Spiro RH. Verrucous carcinomathan and now.Am j surg. 1998; 176(5):393-7. https://doi.org/10.1016/ S0002-9610(98)00232-3

18. Jacobson S, Shear M. Verrucous carcinoma of the mouth. J Oral Pathol.1972; 1(2):66-75. https://doi.org/ 10.1111/j.1600-0714.1972.tb01904.x, https://doi.org/ 10.1111/j.1600-0714.1972.tb02124.x, PMid:4199097

19. Sundstrom B, Mornstad H, Axell T. Oral carcinomas associated with snuff dipping. Some clinical and histological characteristicsof 23 tumours in Swedish males.J Oral Pathol.1982; 11(3):245-51. https://doi.org/ 10.1111/j.1600-0714.1982.tb00162.x, PMid:6808102

20. Stokes, A, Bible J, Halligan E, Orchard G, Edward O, Thavaraj S. Human papillomavirus detection in dysplastic and malignant oral verrucous lesions. Journal of Clinical Pathology.2012; 65:283-286. https://doi.org/10.1136/jclinpath-2011-200454 PMid:22174425

21. Kari J,Syrjänen SS, Syrjänen SM. Papillomavirus infections in human pathology, New York,J Wiley \& Sons 2000 .

22. Rajendran R, C K Sugathan, J Augustaine, D M Vasudevan, T Vijayakuman. Ackerman's tumour (verrucous carcinoma) of the oral cavity: a histopathologic study of 426 cases. Singapore Dent J. 1989; 14(1):48-53.

23. Shear M, Pindborg JJ. Verrucous hyperplasia of the oralmucosa.Cancer.1980; 46(8):1855-62. https://doi.org/ 10.1002/1097-0142(19801015)46:8<1855::AID-CN CR2820460825>3.0.CO;2-\#

24. Bagan JV, Jiménez-Soriano Y, Diaz-Fernandez JM, Murillo-Cortés J, Sanchis-Bielsa JM, Poveda-Roda R, 
et al. Malignant trans $\neg$ formation of proliferative verrucous leukoplakia to oral squamous cell carcinoma: A series of 55 cases. Oral Oncol.2011; 47:732-5. https://doi.org/10.1016/j.oraloncology. 2011.05.008, PMid:21683646

25. Rohan R Walvekar, Devendra A Chauker, Mandra S Deshpande, Prthamesh S Pai, PankajChaturvedi, AnaghaKadade, et al. VC of the oral cavity: A clinical and pathological study of 101 cases. Oral onchology.2009; 45:47-51. https://doi.org/10.1016/ j.oraloncology.2008.03.014, PMid:18620896

26. Demian SD, Bushkin FL, Echevarria RA. Perineural Invasion and anaplastic transformation of VC.Cancer.1973; 32(2):395-401. https://doi.org/ 10.1002/1097-0142(197308)32:2<395::AID-CNCR2 $820320217>3.0 . \mathrm{CO} ; 2-\mathrm{E}$

27. Pentenero, M., Meleti, M.,Vescovi, P. \& Gandolfo, S. Oral proliferative verrucousleucoplakia: are there particular features for such an ambiguous entity? A systematic review.British Journal of Dermatology. 2014; 170:1039-1047. https://doi.org/ 10.1111/ bjd.12853, PMid:24471527

28. Zhu LK, Ding YW, Liu W, Zhou YM, Shi LJ, Zhou ZT. A clin-icopathological study on verrucous hyperplasia and verrucous carci $\neg$ noma of the oral mucosa.J Oral Pathol Med. 2012; 41:131-5. https://doi.org/10.1111/j.1600-0714.2011.01078.x PMid:21913992

29. Wang YP, Chen HM, Kuo RC, Yu CH, Sun A, Liu BY, et al. Oral verrucous hyperplasia: histologic classification, prognosis, and clini $\neg$ cal implications.J Oral Pathol Med. 2009; 38:651-6. https://doi.org/ 10.1111/j.1600-0714.2009.00790.x, PMid:19656267

30. Rekha, KP,AngadiPV. Verrucous carcinoma of the oral cavity: a clinicopathologic appraisal of 133 cases in Indians. Oral MaxillofacSurg, 2010; 14:211-8. https://doi.org/10.1007/s 10006-010-0222-0 PMid:20396919

31. Barnes L, E. J., Reichart P, Sidransky D. WHO Classification of Tumours,Pathology and genetics of head and neck tumours, Lyon: IARC Press; 2005.

32. Mehrotra D, Goel M, Kumar S, Pandey R, Ram H. Oral verrucous lesions: Controversies in diagnosis and management. J Oral BiolCraniofac Res. 2012; 2:163-9. https://doi.org/10.1016/j.jobcr.2012.10.006 PMid:25737860 PMCid:PMC3941283
33. Radhakrishnan, R. Inherited proliferative oral disorder: a reductionist approach to proliferative verrucous leukoplakia.Indian J Dent Res.2011; 22: 365-6. https://doi.org/10.4103/0970-9290.87053 PMid:22048571

34. Yeh, C. J. Treatment of verrucous hyperplasia and verrucous carcinoma by shave excision and simple cryosurgery. International Journal of Oral and Maxillofacial Surgery.2003; 32:280-283. https://doi.org/ 10.1054/ijom.2002.0331, PMid:12767875

35. Regezi JA, Sciubba J. Oral Pathology.ClinicalPathologic correlations.Philadephia, WB: Saunders company 1993.

36. Yoshimura, Y., Mishima, K., Obara, S., Nariai, Y., Yoshimura, H. \&Mikami, T, et al. Treatment modalities for oral verrucous carcinomas and their outcomes: contribution of radiotherapy and chemotherapy. Int J ClinOncol.2001; 6:192-200. https://doi.org/10.1007/PL00012104, PMid:11706557

37. Hashibe M, Jacob BJ, Thomas G, Ramdas K, Mathew $\mathrm{B}$, Zang ZF, et al. Socioeconomic status, lifestyle factors and oral premalignant lesions. Oral Oncol.2003; 39(7):664-71. https://doi.org/10.1016/ S1368-8375(03)00074-5

38. QianPeng, Yuehong Wang, HongzhiQuan, Yiping Li and Zhangui Tang.Oral verrucous carcinoma: From multifactorial etiology to diverse treatment regimens (Review). International Journal Of Oncology 2016; 49: 59-73. https://doi.org/10.3892/ijo.2016.3501 PMid:27121637

39. Tang Z, Xie X, Li J, Liu X, Yao Z and Zhao S: A clinic study on oral verrucous carcinoma phenotypes. Chin J Dent Res. 2005; 8: 5761.

40. Vivekanandh Reddy G, Ramlal G, JitenderRaddy K, RajshekarPatil. Proliferative verrucousleukoplakia and verrucous carcinoma- A Diagnostic dilemmacase report. Ann Essences Dent, 2010; 4:52-6. https://doi.org/10.5368/aedj.2010.2.4.52-55.pdf

41. Santoro, A., Pannone, G., Contaldo, M., Sanguedolce, F., Esposito, V., Serpico, R., et al. A Troubling Diagnosis of Verrucous Squamous Cell Carcinoma ("the Bad Kind" of Keratosis) and the Need of Clinical and Pathological Correlations: A Review of the Literaturewith a Case Report.Journal of skin cancer 2011;370605.https://doi.org/10.1155/2011/370605 https://doi.org/10.1155/2011/370605, PMid:21151509 PMCid:PMC2989749 